\section{SAL 37/2020}

Personal Pronouns in CHET and CECheT: Authorial Presence and Other Nuances Revealed

Received 12/2019

Accepted 07/2020
Personal Pronouns in CHET and CECheT: Authorial Presence and Other Nuances Revealed Asmeniniai ivvardžiai CHET ir
CECheT tekstynuose: autoriaus
matomumas ir kiti niuansai LINGUISTICS / KALBOTYRA

\section{Isabel Moskowich}

University of A Coruña, Spain

\title{
Abstract
}

\section{Introduction}

\section{ktu}

Research Journal Studies about Languages No. $37 / 2020$, pp. $56-73$ ISSN 1648-2824 (print) ISSN $2029-7203$ (online) Doi.org/10.5755/j01.sal.37.1.24809
This paper aims at presenting a portrait of late Modern English scientific writing by studying its use of first-person pronouns. Pronouns reveal authorial presence and their quantification may be helpful. Following previous research (Moskowich, 2017), I have now conducted a qualitative analysis in which pronouns are grouped according to five functions each of them with a different pragmatic value. My research questions include whether there is a tendency from author-centred to object-centred prose over time, whether female writers are more present in their writings than their male counterparts and whether texts belonging to the Humanities (represented here by the Corpus of History English Texts) are also more "subjective" than those belonging to the Hard Sciences (represented by the Corpus of English Chemistry Texts), generally regarded more "objective" and, therefore, more unlikely to contain a high amount of personal pronouns and more so with certain pragmatic functions. The use of variables such as time, sex of the author and discipline allow for a study of change on the one hand and of variation on the other.

KEYWORDS: scientific writing, Coruña Corpus, first-person pronouns, authorial presence, variation.

There are many linguistic features that indicate authorial presence in written texts, even in those belonging to registers where authors tend to disappear behind objectivity. Such is the case with scientific English. In this register, and particularly after the tendency towards detachment, which arose over the course of the twentieth century, we might not immediately think of pronouns as being abundant in a kind of prose devoid of linguistic and rhetorical flourishes, used to achieve an impersonal, objective style. However, the use of pronouns has indeed been found in such writing (Biber, 1988; Hyland, 1996; Atkinson, 1999). First-person pronouns are particularly important in that, as central pronouns (Quirk et al., 1985; Chamonikolasová, 1991), they are especially revealing of the author's presence and his/her involvement in the message conveyed. 
Stemming from the twentieth-century notion that scientific English became detached and object-centred from Empiricism onwards (Atkinson, 1999), my aim in this paper is twofold. First, I ask whether late Modern English scientific texts are devoid of pronouns as a means of showing this detachment. Second, I will conduct a comparative analysis of texts from the History and Chemistry subcorpora of the Coruña Corpus of English Scientific Writing. The reason for this is that they represent different writing traditions, the soft and the hard sciences in the words of Hyland (1996), in which authorial presence may be expected to be shown differently, being more evident in the former. A similar aim was pursued in a previous study (Moskowich, 2017), although in less detail and mainly through a quantitative approach. To complete the picture here I will also consider a number of additional variables that may exert some kind of influence on the use of pronouns.

The paper is structured as follows. Section Scientific English and Personal Pronouns describes the theoretical approaches to scientific English, as well as the opposing views on the functions and intentions behind the use of personal pronouns. Then the material and methodology used for the study is described, followed by the quantitative description and analysis of first-person pronouns according to three variables: discipline, sex of the author, and time. In Section Nominative Pronouns and Communicative Functions, all of these will be addressed from the standpoint of the functions performed by the nominative forms under investigation. After this, a final section will present the main conclusions.

The nature and characteristics of the language of science, and English in particular, began to arouse the interest of scholars in the final years of the twentieth century, perhaps thanks to the theoretical tenets of functionalism (Halliday, 1989, 2004), in which language is seen as an instrument of metaphor and power. If language expresses meanings from the most concrete, physical experiences to those that are more abstract and theoretical, then there is little doubt that science, with its own particular way of communicating information, constitutes the epitome of grammatical metaphor. At approximately the same time as Halliday, Hyland also began to look at the kind of language used in science. Although scholars such as Atkinson (1999) have claimed that scientific English becomes detached and object-centred as time goes by, Hyland $(2001,2005)$ has been able to show that it is not as objective as was initially thought, but, rather, shows authorial presence and stance in various ways. Perhaps this authorial presence, as proposed by Hyland, is related to Halliday's notion of language and power, in that it may be used intentionally on the part of the writer ${ }^{1}$.

Among all grammatical items, few are as closely related to the agents intervening in communicative processes as pronouns. However, pronouns do not only signal who intervenes in the process as either sender (writer) or receiver (expected reader) but are also a manifestation of involvement (Herriman \& Aronsson, 2009) and interaction (Hyland, 2002). In fact, "the clauses with the first-person singular pronoun subjects attribute the attitude they express explicitly to the speaker/writer and are thus subjective interpersonal metaphors" (Herriman \& Aronsson, 2009, p. 103).

As early as 1973, Robin Lakoff began her pioneering research into the connection between language and gender as one of the expressions of the relation between language and power. Indeed, in her dominance approach, she proposed that women are often considered less assertive than men, and she provided a list of linguistic devices which she observed as typical of women's discourse. Among these she noted lexical hedges or fillers (you know, well), tag

\footnotetext{
1 For analyses of involvement and persuasion in IModE scientific writing see Crespo, 2015; Crespo \& Moskowich, 2015; Moskowich \& Crespo 2014; Mele-Marrero, 2017; Moskowich 2017.
} 
questions, rising intonation on declaratives, "empty" adjectives (charming, cute), precise colour terms, intensifiers such as just and so, hypercorrect grammar, very polite forms (indirect requests, euphemisms), absence of strong swear words, and emphatic stress. Unfortunately, Lakoff's work was based on personal observation rather than on empirical study, but she nevertheless paved the way for others to conduct research using empirical methods. The use of personal pronouns can probably be seen as an appropriate additional item on this list of devices typical of female style, in that they are often used to express the mitigation of claims and even a lack of confidence (especially when the plural is used).

In previous work on authorial presence in scientific writing (Moskowich, 2017), I proposed the idea that power asymmetry (Lakoff, 1990) is sometimes perceived in language through women's use of a less detached style than that of men (Argamon et al., 2003). I have also argued that academic writing conveys more than simply knowledge, as it "in some way represents the writer and his/her place within a particular epistemic community" (Moskowich, 2017, p. 75). Given that personal pronouns are a very direct and evident way to show stance, they have been chosen for the present study for a comparison of their use by men and women in samples of prose which are not wholly impersonal (Hyland, 2002). Among all the kinds of pronouns available, first-person pronouns reveal more clearly than any other the author's presence and his/her involvement. Although it is true that most scholars admit that their presence in certain texts is striking and must have a function, there is no agreement as to what this function may be. Thus, Martín-Martín (2003) and Zohar (2015) argue that the singular form of the first-person pronoun is a mark of confrontation (interaction) in the dialogue established in academic prose. An example of this interaction function can be observed in the following extract from my material:

(1) But to leave thofe Salts, and their compendious ways of Preparing, to their own Merits, I fhall now proceed in my intended account of my Sal Solutivum (Packe, 1708, p. 13).

On the contrary, Hyland (2001, p. 217) maintains that the first-person pronoun helps authors to set their own work apart from that of others, as in (2):

(2) THE next fubftance, of whofe effect in reducing metals in the fibres of filk, I fhall treat, is Phofphorus, one of the moft inflammable fubftances, we are aquainted with. (Fullhame, 1794, p. 41).

Similarly, Myers (1992) and Harwood (2005) in their studies on present-day English writing show that the first-person pronoun is used to help the reader identify the author's main claims as well as to provide a sense of novelty for their work.

A disparity of opinions can also be found regarding plural forms. According to some scholars (Myers, 1989), they are used to express modesty (Hyland, 2001), as in example (2) above, whereas others (Pennycook, 1994) argue that they function either as a means of claiming authority or expressing communality (as is the case of inclusive we):

(3) Beginning with the south-western portion of the map of Europe, we find that the country called Spain did not constitute in the tenth century, as it does now, one virtually united territory, but was divided into two clusters of kingdoms (Masson, 1855, p. 79).

Teich (2019), in her analysis of the evolution of the reporting genre of the Transactions of the Royal Society from 1650 to 1850, that is, from Newton to Ada Lovelace, claims that the beginning of the period was characterised by the frequency of personal pronouns and conjunctions, whereas the expository genre of 1850 was characterised by nominal markers and lexical words. 
That said, it is arguable that all these functions need to be better delimited, in the sense that all pronouns have in common the fact that they signal authorial voice or presence in some way. Given that my previous study has already provided quantitative analysis of first-person pronouns (Moskowich, 2017), I will present here a qualitative study in order to classify and assess how the above-mentioned functions are found in two subcorpora of the Coruña Corpus of English Scientific Writing. This will be done not only to analyse the use of pronouns in the discourse of men and women, but also in order to detect whether certain fields tend to employ a more detached style than others and whether such detachment increases over time until we reach the supposedly more object-centred, objective, faceless and impersonal form of discourse (Hyland, 2005, p. 173) typical of the twentieth century.

As noted above, the material for the present study is drawn from the Coruña Corpus of English Scientific Writing (henceforth CC). As the aim of this study is to offer qualitative details about previously quantified data, the same material will be used, namely, the Corpus of History English Texts (CHET) and the Corpus of English Chemistry Texts (CECheT). Text samples for both the eighteenth and nineteenth centuries will be analysed. Both subcorpora were still beta versions at the time of data retrieval, although their completion was well advanced. The information for this study has been retrieved with the Coruña Corpus Tool, CCT (Barsaglini-Castro \& Valcarce, 2019), which allows for access and searches using original spelling, among other features.

The total words under study is 804,454 , that is, approximately 400,000 per discipline. The number of words produced by the sexes is not equally distributed, as one of the premises of the $\mathrm{CC}$ is to place representativeness above balance, and this entails that samples by women must necessarily be less (a total of 111,497 words here) than those by men (692,957); hence, women's writing accounts for only $14 \%$ of the total, as shown in Fig. 1.

The methodology had three main steps. A frequency list was generated with the CCT to ascertain which pronominal forms appeared in the texts. Although authors such as Biber (1988, p. 225) include possessive forms such as my, these were excluded from my list. The final repertoire comprised three singular pronouns (I, me, myself) and three plural ones (we, us, ourselves). The second step was to use the search utility of the CCT to make the queries and thus obtain all examples from the two subcorpora containing the pronouns in question. Finally, after exporting these results into Excel (version 16.25) spreadsheets, the final step consisted of assigning each occurrence of the pronouns to one of the functions mentioned in the section above and set out in Table 1.

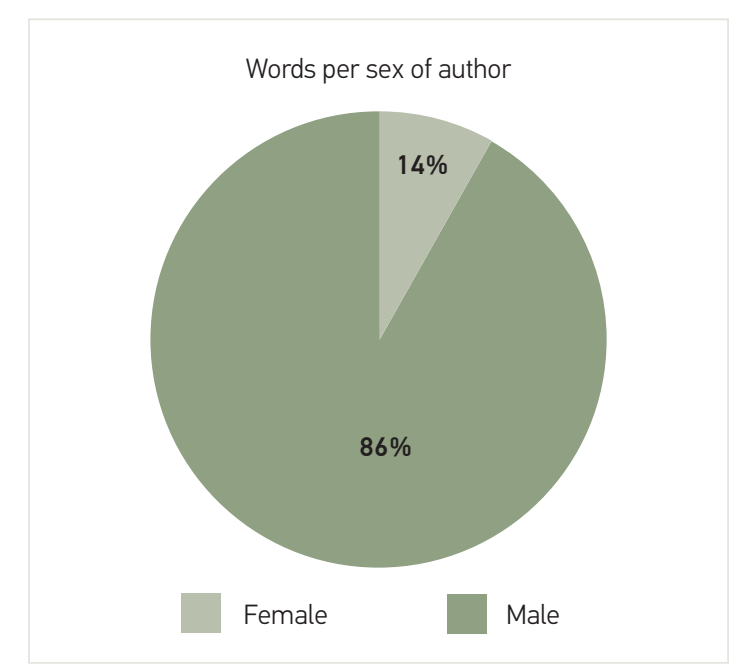

\begin{tabular}{l|l|c} 
Form & \multicolumn{1}{|c|}{ Function } & $\begin{array}{c}\text { Function } \\
\text { code }\end{array}$ \\
\hline $\mathrm{sg}$ & $\begin{array}{l}\text { mark of confrontation (Martín- } \\
\text { Martín 2003), dialogue, interaction }\end{array}$ & 1 \\
\hline & $\begin{array}{l}\text { set one's work apart (Hyland 2001), } \\
\text { identify author's main claims (Myers } \\
\text { 1992; Harwood 2005), give sense of } \\
\text { novelty to work }\end{array}$ & 2 \\
\hline $\mathrm{pl}$ & $\begin{array}{l}\text { express modesty (Myers 1989), } \\
\text { mitigation }\end{array}$ & 3 \\
\hline & $\begin{array}{l}\text { claim authority and communality } \\
\text { (Pennycook 1994) }\end{array}$ & 4 \\
\hline $\mathrm{sg} / \mathrm{pl}$ & \begin{tabular}{l} 
description/narration of facts \\
\hline
\end{tabular}
\end{tabular}

\section{Corpus Material and Methodology}

Fig. 1 Words per sex

Table 1 Function of firstperson pronouns in scientific writing 


\section{Analysis of Data}

\section{Table 2}

Frequency of firstperson pronouns in the corpus
During the revision process for each example, in order to assign them to one of the possible five functions (numbered, as shown in Table 1), I detected that oblique cases were not easily ascribable to any specific function. This happened, for example, when analysing the form myself. It appeared on only five occasions in CHET (in the eighteenth century), four of which were from the writing of one woman, Elizabeth Justice (1739), as in example (4):

(4) I thought myfelf very lucky in having an Opportunity of feeing fo fine a Place as that really is; and at the fame time to have the Favour of feeing Numbers of the Courtiers (Justice, 1739, p. 9).

The occurrence in this extract is not easily assignable to a particular function as it could be interpreted as the statement of a mere fact (function 0), some way of interaction with the reader through the author sharing her feelings (function 1), or even the making of a claim (function 2). The same lack of functional clarity was found for all oblique cases. In order to obtain a more consistent study, I excluded all such examples and retained only nominative forms for further scrutiny.

The above methodology yielded 4,156 pronominal forms (roughly $0.5 \%$ of the 804,454 words in the corpus material). Plural and singular forms (with 2,114 and 2,042 tokens, respectively) are more or less equally frequent. However, $I$ is the pronoun appearing most often (1,886 times), followed by we $(1,630)$, whereas all the oblique forms recorded amount to only 640 tokens. At the other end of the scale, reflexive pronouns (excluded from the functional analysis) appear only seldom (myself on 23 occasions and ourselves on 11). Table 2 sets out all these findings.

\begin{tabular}{c|c|c} 
Form & Tokens in CHET & Tokens in CECheT \\
\hline$I$ & 428 & 1,458 \\
\hline$m e$ & 50 & 155 \\
\hline myself & 6 & 17 \\
\hline we & 448 & 1,182 \\
\hline us & 149 & 252 \\
\hline ourselves & 6 & 5 \\
\hline Total & 1,087 & 3,069 \\
\hline
\end{tabular}

Further a detailed account of the behaviour of the two nominative forms, considering the three extralinguistic variables mentioned above, is provided.

\section{Distribution of Personal Pronouns per Discipline}

When examining the distribution of personal pronouns in the two disciplines under study, it is immediately noticeable that pronominal forms are more abundant in the texts dealing with Chemistry, with a total of 3,069 tokens, three times as many as in History texts (1,087 first-person pronouns). One

would probably expect to find the opposite if we consider that pronouns are indexical of involvement, and that the Humanities (represented here by History texts) are regarded as more subjective than the Exact Sciences (represented by Chemistry).

However, not all these pronominal forms are in the nominative, the ones whose function will be analysed here. Of the 3,069 tokens in Chemistry, 2,640 correspond to nominative forms, whereas in History we find only 876 from a total of 1,087 tokens. This distribution is certainly not the expected one, as our initial hypothesis (Crespo \& Moskowich, 2015; Moskowich, 2017) was that stance expressed in the form of pronouns would be more abundant in History texts. The following subsection will briefly focus on how the use of these subject forms evolves from the eighteenth to the nineteenth century.

Of the total of 3,516 subject forms, 2,114 (51\%) correspond to the singular $I$ whereas 2,042 (49\%) correspond to the plural we. The implications of this distribution will be better un- 
derstood in the following pages as the different functions attributed to them are discussed.

\section{Distribution of Personal Pronouns over Time}

Time is the second variable used for the analysis. If Atkinson's (1999) idea of a tendency from author-centred to object-centred discourse is true, we should observe a more restricted use of pronouns in the texts from the nineteenth century than in those from the eighteenth ${ }^{2}$. This does seem to be the case for my data, as the samples contain fewer of these forms over time. So, the number of tokens (for oblique and non-oblique cases) recorded for the eighteenth century is 2,509, whereas for the following period the total is 1,647 . Fig. 3 sets out the diachronic evolution of the use of first-person pronouns in general, disregarding the evolution for each field.

The frequency of each of the forms initially contemplated (Moskowich, 2017) shows that, although the two disciplines are represented by the same number of words, Chemistry texts (CECheT) contain twice as many of these forms in the eighteenth century as History texts (CHET). Yet more extreme differences can be seen for the period between 1800 and 1900 (see Table 3).

On closer inspection, however, and as set out in Fig. 4 (see page 62), we observe that although there is a greater number of pronouns in CECheT, there is
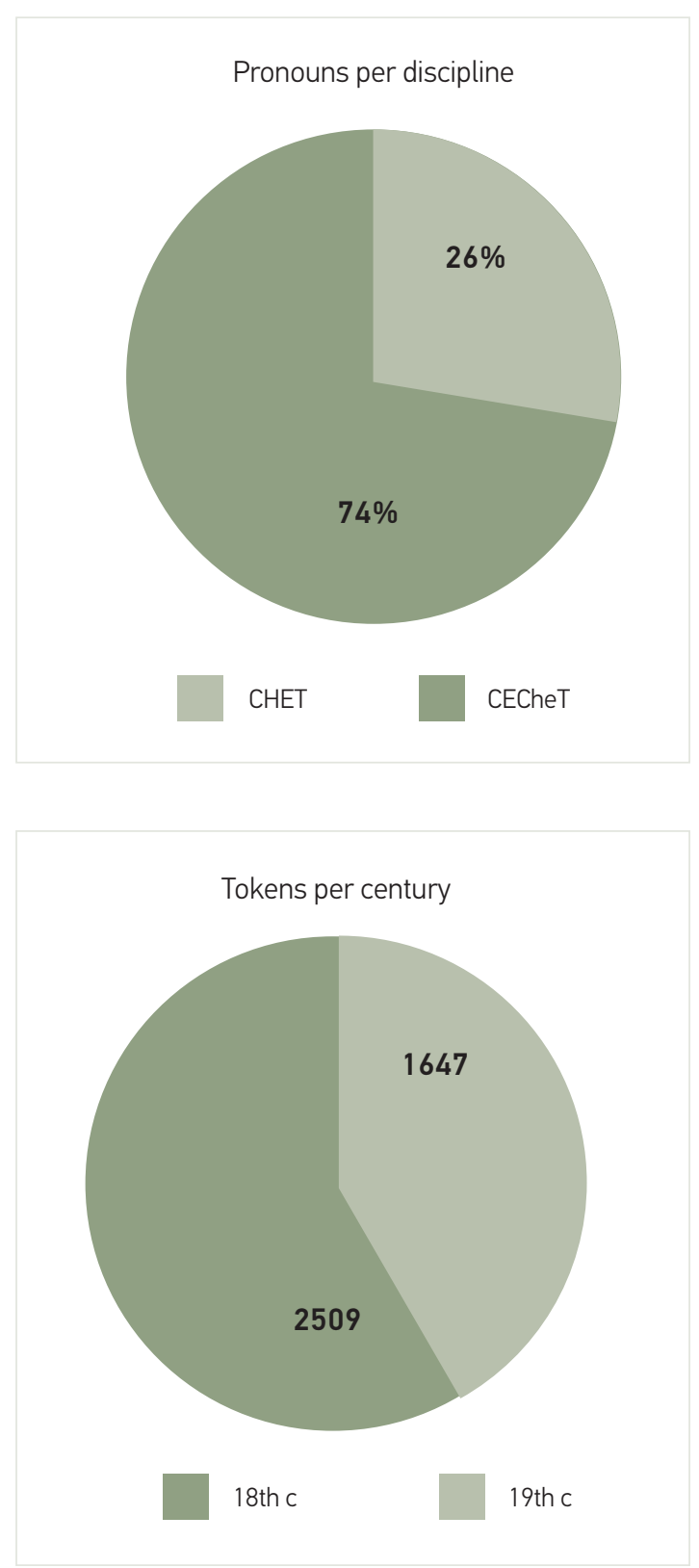

Fig. 2

Presence of first-person forms in the disciplines

Fig. 3

Use of personal pronouns per century

a general decrease in their use in both domains, the diachronic evolution of the disciplines being quite similar. Whereas the tendency towards objectivity (as regards the use of fewer pronouns) is perceptible in the samples from CHET, with 837 tokens in the first subperiod and 250 in the second, the texts in CECHeT seem to undergo a far less dramatic adaptation to the new trends, from 1,672 personal pronouns in the eighteenth-century samples to 1,397 for the following period. This surprisingly different evolution may be due to the small number of pronouns found in History texts as compared with those dealing with Chemistry. However, knowing whether this is a reflection of the nature of Humanities genres in general, rather 
Table 3

Distribution of all first-person forms per century and discipline

\begin{tabular}{l|c|c|c|c}
\multirow{2}{*}{} & \multicolumn{2}{|c|}{ CHET } & \multicolumn{2}{c}{ CECheT } \\
\cline { 2 - 5 } & 18 th century & 19 th century & 18 th century & 19 th century \\
\hline me & 400 & 28 & 932 & 526 \\
\hline myself & 45 & 5 & 84 & 71 \\
\hline we & 5 & 1 & 7 & 10 \\
\hline us & 265 & 183 & 508 & 674 \\
\hline ourselves & 120 & 29 & 140 & 112 \\
\hline TOTAL & 2 & 4 & 1 & 4 \\
\hline
\end{tabular}

Fig. 4

Use of all pronominal forms per century and discipline

\section{Evolution of pronouns per discipline}

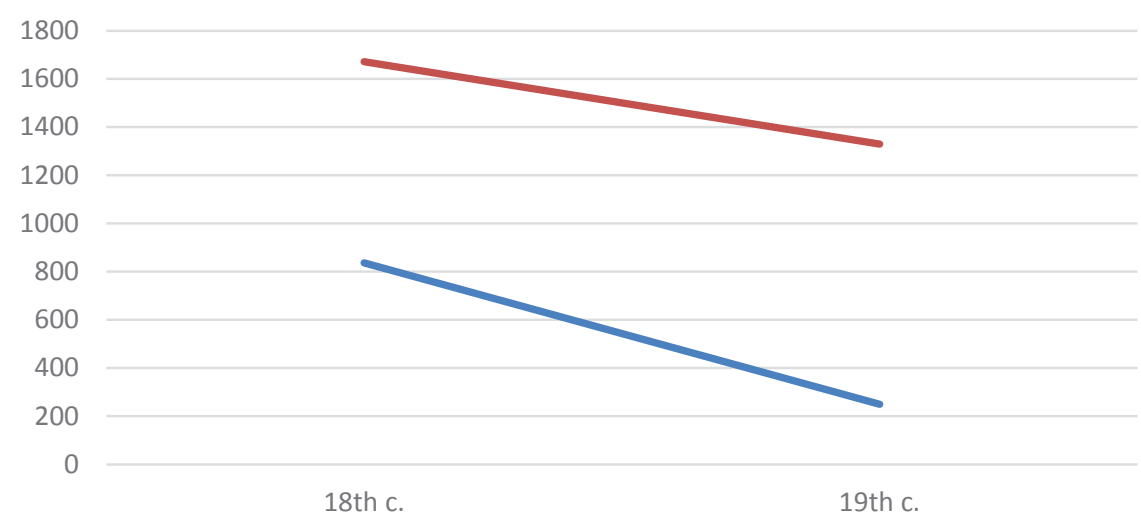

$\longrightarrow$ CHET $\longrightarrow$ CECheT

than an idiosyncrasy of these particular History samples, would require extending the study to other, related disciplines, and as such, falls outside the scope of the present paper.

Besides, when considering only the nominative cases of the pronoun (see Fig. 5), we also observe that in the 3,516 tokens the form $I$ occurs almost half as frequently in the nineteenth century as in the eighteenth century (1,332 hits for the eighteenth and 554 for the nineteenth century), which is in accordance with the general decrease in the use of pronouns ${ }^{3}$. At the same time, the use of we remains more or less stable, with 773 occurrences in the eighteenth-century section of the corpora and 791 in the nineteenth-century section.

My data reveal that History texts also used the pronoun / more often in the period from 1700 to 1800 than in the following one; 400 cases for the eighteenth century in contrast to the 28 found in the nineteenth. This may be interpreted as a sign that the Humanities were also undergoing a transformation from less to more object-centred (Atkinson, 1999) and, as Fig. 5 below

3 This general tendency can also be detected in women writers. Of the two women writing about Chemistry recorded for the 1800-1900 period, Marcet (1806) and Richards (1882), only the former uses the pronoun I. Richards does not use it at all, preferring we. This preference for we can be related to modesty, as we will see later on. 


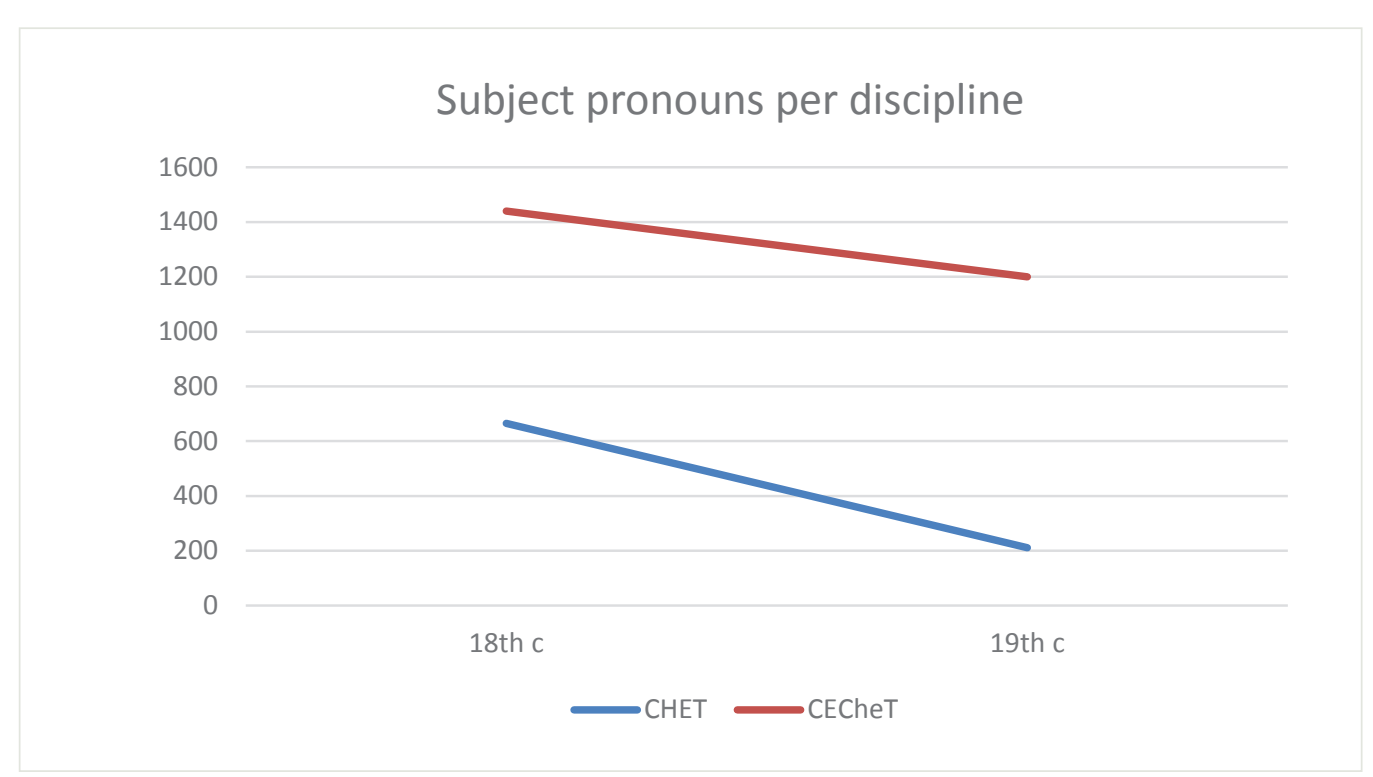

shows, the evolution of both disciplines over time is almost parallel, although the decrease in the use of pronouns is slightly clearer in CHET than in CECheT. In the next subsection, we will look at the way in which these nominative forms are used according to the sex of the writer.

\section{Distribution of Personal Pronouns per Sex of Author}

Argamon et al. (2003) argue that women writers tend to include features expressing involvement in their written discourse, such as first-person pronouns. The same idea is posited by Schlomo et al. (2003), who claim that there are significant differences between male- and female-authored documents in the use of personal pronouns. Despite this, there does not seem to be a huge difference in my material in terms of numbers.

Although the analyses of the two former variables (discipline and time) did not require the use of any proportional comparisons, in that the CC contains approximately the same amount of words to represent each century and each discipline, when comparing the use of pronouns by men and women writers, figures have been normalised to 10,000 words since the volume of material written by the former is larger than the latter. Fig. 6 below sets out the slightly higher number of pronouns found in female writing in the two disciplines following normalisation.

Use of pronouns per sex(nf)

\section{5,83}

Despite the limited difference in the general use of pronouns by the sexes (45.83 in women writers vs 43.39 in men writers, nf), we can see this is much greater when analysing forms in detail. In fact, Fig. 7 (see page 64) shows that men use the singular form more often than women (34.85 vs 20.36 , nf) whereas the latter seem to prefer to mitigate their presence with we more readily than men ( 45.47 vs $19.4, \mathrm{nf}$ ).

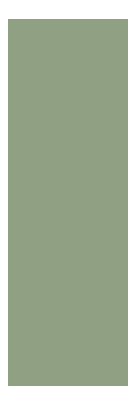

Female
Fig. 6

Use of first-person pronouns per sex (nf/10,000 words) 
Fig. 7

Use of singular and plural pronouns by men and women

\section{Nominative}

Pronouns and Communicative Functions

Fig. 8

Pronouns and their functions in the corpus
Use of sg. and pl. per sex

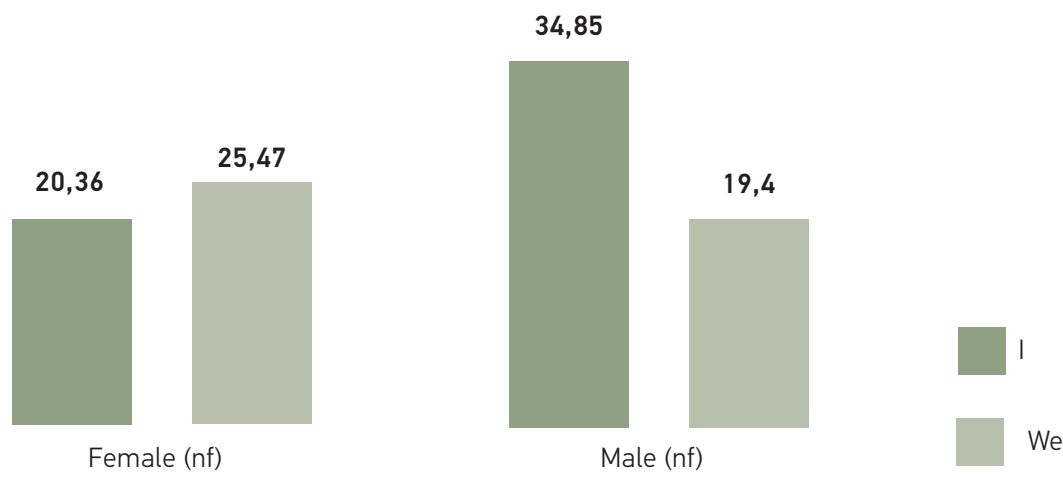

Although the CC contains only one sample per author in order to avoid the potentially skewing effect of any writer's idiosyncrasies, it is perhaps worth mentioning that the highly frequent use of $I$ in texts by men may in some way be caused by the amount of tokens found in the samples from two nineteenth-century Chemistry texts, namely, those by Faraday and Brodie. As regards History, all the uses (28 hits) of $I$ in the nineteenth-century section of CHET correspond to four men authors. In fact, the one that uses it most frequently (19 times) is Smyth (1840), probably due to the oral nature of his text, a lecture.

After this very general revision of the quantitative data in Moskowich (2017), an exploration of the functions of these pronouns may lead to more interesting insights in terms of stance and authorial presence in scientific writing.

As noted above, the analysis of data has been completed by the close reading of each of the 3,516 occurrences of the pronouns $I$ and $w e$ in their context in order to ascertain the communicative function they performed in each case. All the five functions identified in above were found in the texts.

Fig. 8 shows the five functions identified and set out in Table 1, and their distribution in my material. As can be seen, the most abundant function, with 1,163 hits, is the descriptive one (which

\section{Overall distribution of functions}

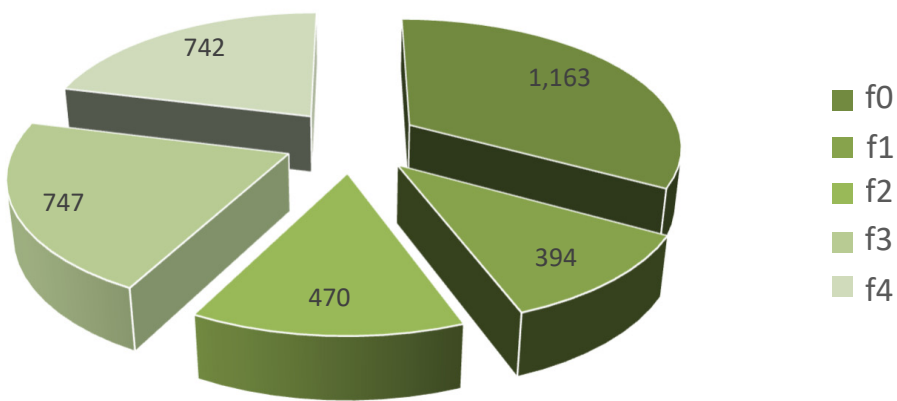


I have labelled function 1), found to occur in both the singular and plural forms. This is followed by the function I have encoded as 3 , typical of the plural form we, described in the literature as a mitigating resource; 747 tokens were found in my material. Almost the same number of occurrences of $w e$ (742) are used to express function 4, that is, claiming authority and communality (Pennycook, 1994). The singular form is identified with function 0 (description) and also with functions 1 (mark of confrontation (Martín-Martín, 2003), dialogue and interaction) and 2 (used to set one's work apart (Hyland 2001), to identify the author's main claims (Myers 1992; Harwood 2005), or to give sense of novelty to one's work). There are 470 occasions on which the pronoun is used to establish some kind of claim, whereas the dialogic function appears only 394 times in the two subcorpora. These overall numbers may tell us something about the stylistic tendencies of the period, but more information can be obtained by considering frequency per discipline, century, and the sex of the writer, as I did for the general figures.

\section{Pronouns, Their Functions and Other Factors}

The use and functions of language are determined by external factors, although speakers or writers are not always aware of this, and some of the linguistic features and functions they resort to may be the result of an unconscious process or a mere social tendency that is followed by the author. If the latter is the case, the behaviour of scientific disciplines may be different here, and thus we may find that functions are not used equally in History and in Chemistry texts. Fig. 9 below presents the data from my classification of functions of $I$ and we for both fields of study.

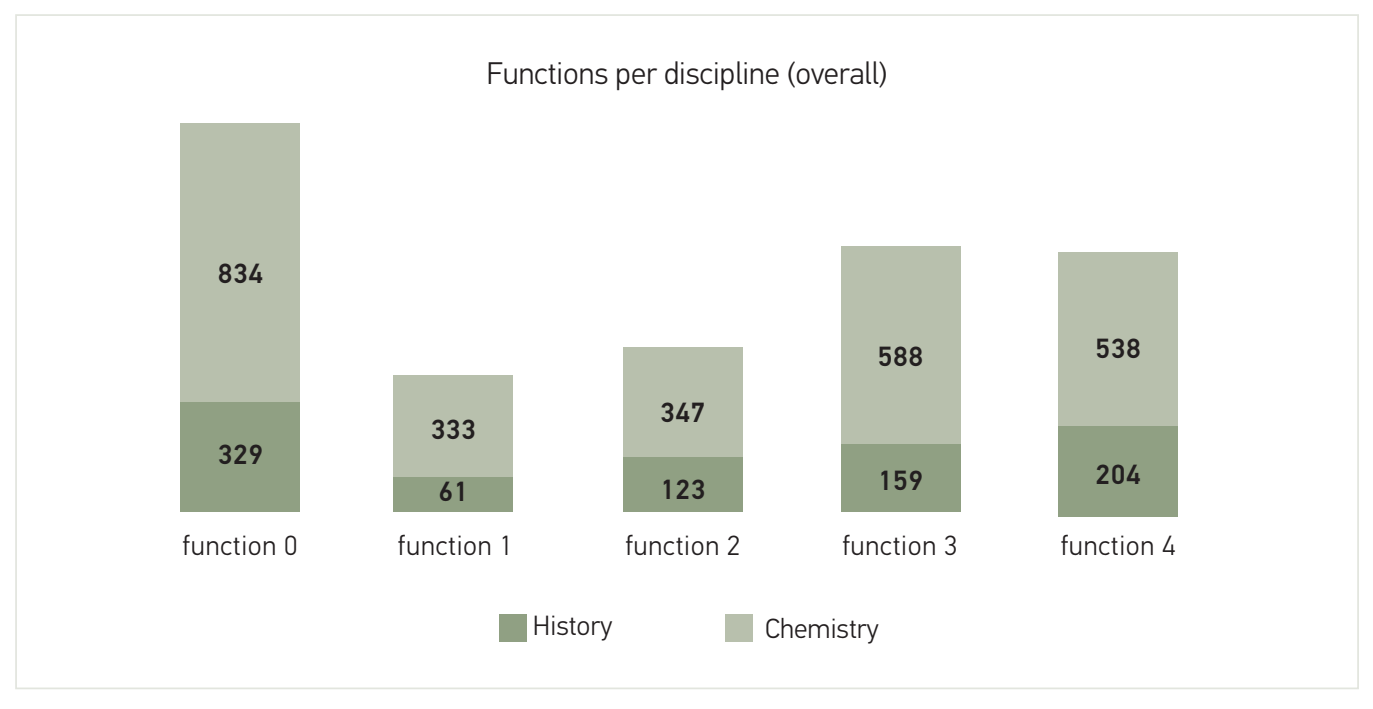

Fig.9 illustrates not only that not all the functions performed by first-person pronouns are equally recorded in my material, as already shown in Fig. 8, but also that all such functions are more often found in Chemistry texts. As the two subcorpora have the same size and are directly comparable, raw numbers were used. Thus, we can see that the function of the personal pronoun that appears most often is function 0 , that is, description or narration of facts, with 834 cases in Chemistry texts. This is the only function that is not directly associated with either the singular or the plural form, and this itself may explain its abundance. Although description and narration could be thought to be more intimately related to History texts, we ought to bear in mind that during the late Modern English period many scientific texts consisted of a detailed account of experiments, and this may explain why we have so many of these in the CECheT. 
Function 3, associated with modesty or the mitigation of statements, is the second most frequently attested one, with 588 tokens. This is found in the plural and, in the case of Chemistry texts, it appears in instances such as (5) where we is used to refer to the author himself, not to anyone else.

(5) Firft, That Springs are deriv'd and fed by Rains and Dews, hath the higheft Probability, in that they ceafe on Want of Rain, and flow from the Supply of it; which hath the Force of a fenfible Conviction: What other way do we feek to prove any Caufe? (Allen, 1711, p. 3).

Following this, we find function 4 , also associated with the plural form and generally used to denote either a claim of authority or communality. There are 538 such instances in CECheT, which is perhaps of little surprise in that the creation of institutions such as the Royal Society favoured the sense of sharing knowledge and belonging to an epistemic community.

Functions of the singular pronoun are found less frequently. Thus, function 2 (giving a sense of novelty, setting one's work apart, or reinforcing one's main claim) appears on 347 occasions, and function 1 (with a dialogic character) some 333 times.

In turn, the samples belonging to the History subcorpus contain fewer instances of pronouns and hence also of each of these functions, which are quite evenly distributed. Once more, the most abundant function is that used to describe or narrate facts, function 0 (found in both the singular and the plural), with 329 cases. As in the case of Chemistry, we find that functions typical of we are also more commonly found in CHET. Thus, there are 204 cases of function 4, and 159 of function 3 . The singular, not very frequently used by the authors in these samples, does occur, with $I$ appearing 123 times to make some kind of claim (function 2) and 61 times to indicate some kind of interaction or dialogue.

In what follows, I will try to describe how these functions are used over time.

\section{Pronominal Functions and Time}

The five different functions identified for personal pronouns do not behave in the same way. In fact, writers seem to change the intention with which they use pronominal forms, perhaps depending on external factors such as prescriptive guidelines imposed by societies and institutions. Even when not writing for these, writers may have become accustomed to a particular style found in other works, that is, a more or less unconscious process of standardisation is taking place.

The data from my material reveal that this change in the pragmatics of pronouns occurred over time, as shown in Fig. 10.

There is an evident decrease in the use of first-person pronouns, both singular and plural, to describe situations or to narrate facts (function 0). This is in accordance with the tendency to seek a more objective discourse where writers adopt a position of narrating facts not from the standpoint of the observer. The function by which authors contrast or counterpose their own opinions with those of their audience (which could be interpreted as a dialogic function) decreases during the transition from the eighteenth to the nineteenth century, as does function 2 (to set one's work apart), although to a lesser extent. All these movements seem to be part of the same tendency towards objectivity and a sense of detachment from what is being presented.

Likewise, there is an increase of functions 3 and 4, both typical of the plural. Thus, there is a modest rise in the use of function 4 (to promote a sense of communality), and authors thus seem to pursue the approval of their reading public when they write. But the function that increases most is that by which we is used to reflect modesty rather than inclusion, something still seen in the twentieth century. 


\section{Evolution of pronominal functions}

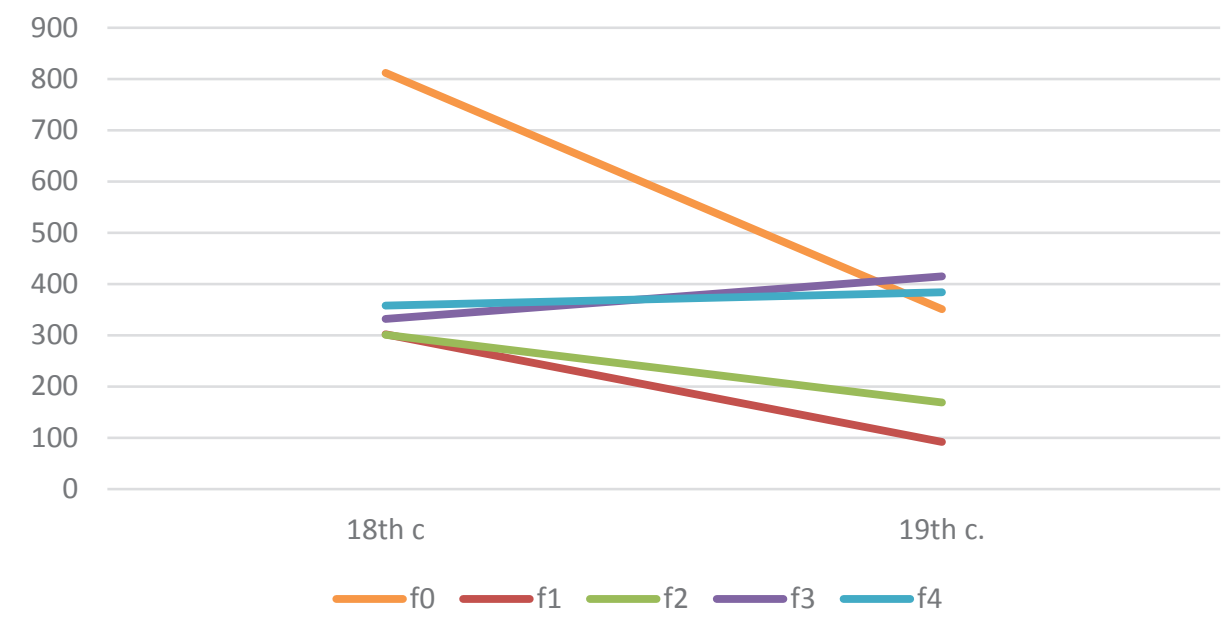

It is worth looking more closely at these nuances in the two disciplines under discussion here, to see whether the difference between the Humanities and the Hard Sciences is as real as is often claimed.

\section{Diachronic Evolution of Pronoun Functions in Chemistry and History Texts}

When combing the results for counting and reading, the pattern of distribution of these functions by discipline and over time are indicative of different writing practices in the two fields, as the tables below show.

The data for the singular pronoun in Table 4 reveal that in both disciplines the descriptive or narrative function (function 0 ) is used in abundance. However, mitigating we is more frequently found in Chemistry than in History. This may be due to the fact that writers dealing with Chemistry were perhaps more aware that their writing was not essentially a matter of opinion, whereas authors writing about historical events, especially before the emergence of Historiography, were not thus constrained, and indeed in those cases where they resorted to the plural form they often made claims or included the audience in them quite freely (function 4, with 125 uses, is the preferred one in CHET).

Table 5, in turn, sets out the distribution of pronominal pragmatic functions in the two disciplines under survey for the nineteenth century, in which we see a decrease in the descriptive/narrative use of pronouns, which, as mentioned earlier, is quite dramatic in the case of History. We can also see that writers of Chemistry texts set their own work apart more often than those writing about History, who persist in using function

\begin{tabular}{c|c|c} 
Function & $\begin{array}{c}\text { Cechet 18th } \\
\text { century }\end{array}$ & $\begin{array}{c}\text { Chet 18th } \\
\text { century }\end{array}$ \\
\hline 0 & 490 & 322 \\
\hline 1 & 254 & 48 \\
\hline 2 & 188 & 113 \\
\hline 3 & 275 & 57 \\
\hline 4 & 233 & 125 \\
\hline
\end{tabular}

\begin{tabular}{l|l|l} 
Function & $\begin{array}{c}\text { Chemistry19th } \\
\text { century }\end{array}$ & \multicolumn{1}{|c}{$\begin{array}{c}\text { History 19th } \\
\text { century }\end{array}$} \\
\hline 0 & 344 & 7 \\
\hline 1 & 79 & 13 \\
\hline 2 & 159 & 10 \\
\hline 3 & 313 & 102 \\
\hline 4 & 305 & 79 \\
\hline
\end{tabular}

Fig. 10

Evolution of pronominal functions in time 
Fig. 11

Distribution of functions per discipline (18th century)

Fig. 12

Distribution of functions per discipline (19th century)
3 (modesty or mitigation) more often than the former. This may be because although they are aware of Historiography as a newly emerging discipline at the time, it cannot as yet be considered a science, and hence some caution is required.

All these observations can be better seen graphically, and in Figs. 11 and 12, each of the pronouns and their functions can be seen, making an understanding of their behaviour easier.

Fig. 11 shows that authors of the History texts produced during the nineteenth century preferred the singular to describe or narrate events, to provide a sense of novelty or, more rarely, to make claims. By contrast, the plural was reserved to express mitigation or modesty. In Chemistry, however, the singular was more often used to establish a dialogue with the reader than to make claims, which seems to be an attitude more typical of the Humanities (often considered more dialogic). As for the plural form, authors writing about Chemistry use

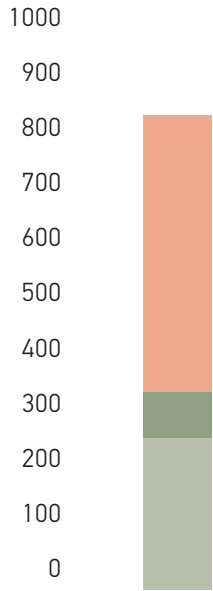

f0
Functions and disciplines (18th c)

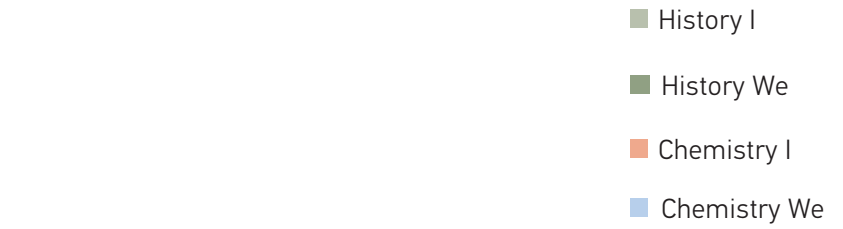

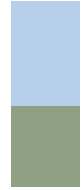

f3

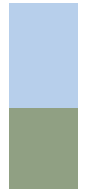

f4

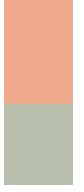

†2

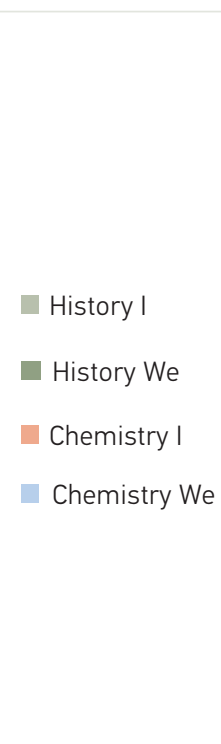

Functions and disciplines (19th c)

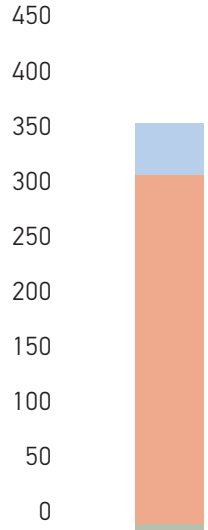

f0

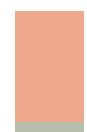

f1

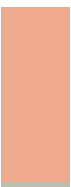

f2

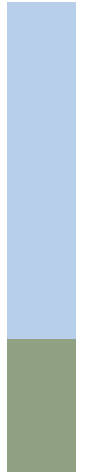

f3

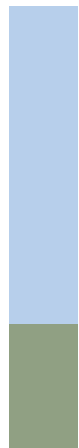

- History I

History We

Chemistry I

Chemistry We 
it for function 4 (communality) and only in a few cases to express function 3 (modesty). This may be interpreted as a sign that the authors whose texts are contained in CECheT are more clearly conscious of belonging to a particular epistemic community (that of "men of science") than the ones writing the samples in CHET.

Fig. 12 in turn displays the distribution of pragmatic functions of the pronouns used in the nineteenth century in the two disciplines. The first point of departure from what occurred in the previous century is the overwhelming use of pronouns for description in Chemistry texts. Of those, most are expressed by the singular form $I$. The singular pronoun, very rarely used in History texts, is preferred to convey function 1 (interaction or dialogue, 13 uses) in the first place, and only in the second place to make claims (10 uses). The same form is used very abundantly (158 occurrences) in Chemistry to make claims, followed by dialogic uses, this at only half the frequency (79 hits).

As for the plural form, we can also see that it is used by writers of the two disciplines in very different ways ( 505 cases in CECheT and 183 in CHET) and with a very different distribution. Whereas History writers use $w e$ in a narrative function on only two occasions, Chemistry writers resort to this function 55 times, which is surprising if we consider that Chemistry is not regarded as the type of field where the writer is typically thought of as describing facts from his/her own point of view but, rather, objectively. Function 3, used in order to mitigate claims or to express modesty, is also attested more often in CECheT than in CHET (102 examples in History vs 267 in Chemistry), and the same happens with the expression of communality, as we saw above (79 cases in History vs 286 in Chemistry).

In general terms, all these results can be said to be directly caused by the fact that Chemistry writers tend to use more pronouns in the nominative case than History writers, which is itself a surprising finding.

\section{Pronouns, Their Functions and the Sex of Writers}

This part of the analysis requires normalising figures since, unlike for the variables of time and discipline, the corpora do not contain the same numbers of words by men and women authors; as mentioned earlier, there are only three samples by women in CECheT and eight in CHET.

The way in which men and women writers use first-person subject pronouns is set out below.

Fig. 13 shows some surprising results regarding the initial assumptions that women may have tended to use functions indexical of involvement more often than men. The normalised figures show that women use pronouns for description or narration of events more often than for any other function ( $26.3 \mathrm{nf})$. The next function in terms of frequency is function 2 , the

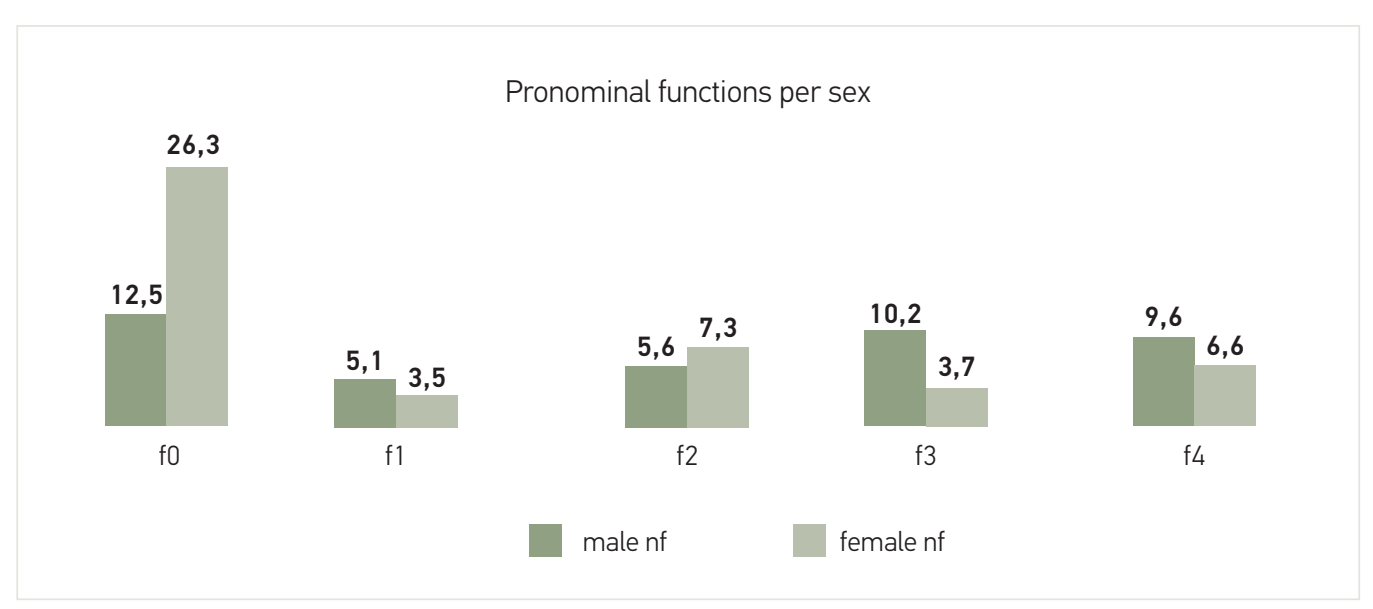

Fig. 13

Distribution of pronominal functions per sex 
Fig. 14

Pragmatic functions per discipline according to the sex of the author one that sets one's opinion apart, used to make main claims, or to give a sense of novelty. Against these findings, the results found for men are radically different: they also prefer the descriptive function most frequently (function 0 , with $12.5 \mathrm{nf}$ ) but this is followed by the function associated with mitigation of their own opinions or views (function 3), which is the function men authors seem to use less often (10.2 nf). This behaviour seems to reflect the way in which women had to overcome the difficulties of the androcentric world they lived in, resorting to a clearly assertive style, whereas men, perhaps buttressed by a sense of entitlement based on their sex, could afford to express their views in a less aggressive way.

We observe that certain women authors use function 2 for $I$ abundantly, that is, they use it to make claims. I have found many examples from authors such as Marcet (1806). This is surprising in that not only is she a woman, but the characters of her dialogue are also women (Mrs B., Caroline and Emily). In the following example, it is Mrs. B who is speaking to her young interlocutors:

(6) It would be an extremely expensive, and, I believe, very imperfect method; for the action of the acid on the wood, and the heat produced by it, are far from sufficient to deprive the wood of all its evaporable parts. (Marcet, 1806, p. 25).

Fig. 14 shows the women's preference for function 0 . This may, however, be due to the presence of a particular text in the corpus, a sample from the work $A$ Voyage to Russia by Elizabeth Justice (1739), a diary-like travelogue, in which the author narrates her journey in the first person. Apart from this, pronominal functions in texts dealing with History seem to be more or less equally distributed in the two sexes, whereas samples dealing with Chemistry seem to use pragmatic functions in a different way. In the latter, men resort to the use of we with its value of modesty (function 3) more often than women, who prefer to use function 2, the one that sets their work apart. This, again, may be interpreted as an overreaction, an excessively assertive style demanded of them due to the social circumstances in which they were writing.

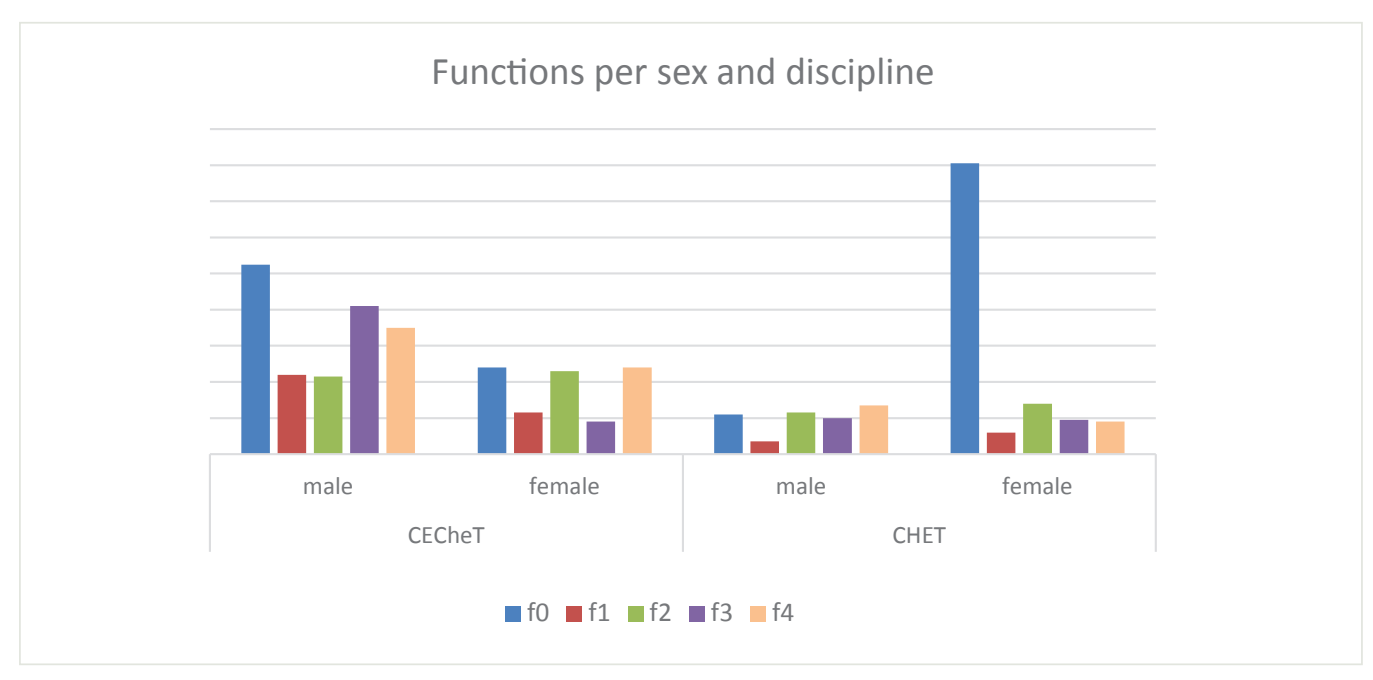

This paper examined how the use of first-person pronouns evolved over time and varied depending on discipline, and the sex of the author. I sought to understand whether language became more object-centred in my material, as Atkinson (1999) had observed for the Transactions of the Royal Society. The well-known idea that scientific English tends to be more 
objective as time goes by needed to be proved by delimiting and studying specific linguistic features. Focusing exclusively on first-person pronouns, this microscopic study showed that the scientific register becomes more objective perhaps not only because fewer tokens of pronouns are found in the nineteenth century as compared with the eighteenth but, more importantly, because of the nuances of meaning that they convey. Thus, of the five functions I have identified here, the one with a more neutral meaning (the descriptive one) is also the one that was most frequently used by the forty-one authors examined.

Another research question addressed in this paper was whether there existed any differences in the way writers in the hard and the soft sciences used pronouns and their different functions. I compared texts from one discipline of each type, Chemistry and History, to ascertain whether the latter contained more pronouns than the former, an assumption based on the fact that the Humanities have traditionally been considered more subjective than the Hard Sciences. Unexpectedly, the texts in CECheT (on Chemistry) contain more pronominal forms than CHET (on History). Besides, in terms of the functions of those pronouns, the use of a mitigating, modesty $w e$ is more frequent in CECheT, whereas the form preferred to make claims and also to refer to common knowledge is the outstanding one in CHET. Again, these uses seem to contradict our initial ideas about disciplines.

Thirdly, I was interested in analysing the use of pronouns in relation to the sex of the author. In the literature on language and gender, women have generally been seen to show their voice more often than men. My findings, however, show that although this is true, a more pertinent approach is to consider the pragmatic functions that these forms carry out. Thus, according to my data, women prefer to use the singular pronoun in a dialogic way as a mark of confrontation, and the plural in function 4 (to claim authority or to indicate communality). In this sense, my findings seem to contradict Lakoff's claim that women are less assertive then men. Quite surprisingly, I found that men, in turn, resort more often to we to express modesty.

In Moskowich and Crespo (2014, p. 101), we argued that "[o]ne of the ways of manifesting such personal opinions is the incorporation of stance adverbs into one's discourse" and I have shown here that the role of personal pronouns in this respect is no less notable. This first approach to the study of pronouns also showed that "[t]he use of first and second person pronouns is undoubtedly one of the devices used by authors either to involve the reader, or to show their own involvement with and proximity to both the message conveyed and the readership" (Crespo \& Moskowich, 2015, p. 78). With the detailed consideration of the functions performed by these linguistic elements, I hope I have shed light on the significant role of personal pronouns in scientific English as a means of revealing not only the presence of authors but also their attitudes towards what they are writing about and, more importantly, towards their readership.

1 Argamon, S., Koppel, M., Fine, J., \& Shimoni, A.R. (2003). Gender, genre, and writing style in formal written texts. Text, 23(3), 321-346. https://doi. org/10.1515/text.2003.014

2 Atkinson, D. (1999). Scientific Discourse in Sociohistorical Context: The Philosophical Transactions of the Royal Society of London, 1675-1975. Mahwah, NJ: Lawrence Erlbaum. https://doi. org/10.4324/9781410601704
3 Barsaglini-Castro, A., \& Calcarce, D. (2019). The Coruña Corpus tool: Ten years on. Revista del Procesamiento del Lenguaje Natural, 64, 13-19.

4 Biber, D. (1988). Variation across Speech and Writing. Cambridge: Cambridge University Press. https://doi.org/10.1017/CB09780511621024

5 Chamonikolasová, J. (1991). Pronouns, functional sentence perspective and intonation. Brno Studies in English, 19, 55-64.

References 
6 Crespo, B. (2015). Women writing science in the eighteenth century: A preliminary approach to their language in use. Anglica: An International Journal of English Studies, 24(2), 133-128.

7 Crespo, B., \& Moskowich, I. (2015). Involved in writing science: nineteenth-century women in the Coruña Corpus. International Journal of Language and Linguistics, 2(5), 76-88.

8 Halliday, M.A.K. (1989). Some grammatical problems in scientific English. In Genre and Systemic Functional Studies, Australian Review of Applied Linguistics, 6, (pp. 13-37). https://doi. org/10.1075/aralss.6.02hal

9 Halliday, M. A. K. (2004). The Language of Science. London: Continuum.

10 Harwood, N. (2005). We do not seem to have a theory... The theory I present here attempts to fill this gap: Inclusive and exclusive pronouns in academic writing. Applied Linguistics, 26(3), 343375. https://doi.org/10.1093/applin/ami012

11 Herriman, J., \& Aronsson, M. B. (2009). Themes in Swedish advanced learners' writing in English. In Aijmer, K. A. ( Ed.), Corpora and Language Teaching (pp. 101-120). John Benjamins. https:// doi.org/10.1075/scl.33.11her

12 Hyland, K. (1996). Talking to the academy: Forms of hedging in science research articles. Written Communication, 13(2), 251-281. https://doi. org/10.1177/0741088396013002004

13 Hyland, K. (2001). Humble servants of the discipline? Self-mention in research articles. English for Specific Purposes, 20, 207-226. https://doi. org/10.1016/S0889-4906(00)00012-0

14 Hyland, K. (2002). Authority and invisibility: Authorial identity in academic writing. Journal of Pragmatics, 34(8), 1091-1112. https://doi. org/10.1016/S0378-2166(02)00035-8

15 Hyland, K. (2005). Stance and engagement: a model of interaction in academic discourse. Discourse Studies, 7(2), 173-192. https://doi. org/10.1177/1461445605050365

16 Lakoff, R. T. (1973). Language and woman's place. Language in Society, 2, 45-80. https://doi. org/10.1017/S0047404500000051

17 Lakoff, R. T. (1990). Talking Power: The Politics of Language in Our Lives. New York: Basic Books.
18 Martín-Martín, P. (2003). Personal Attribution in English and Spanish scientific texts. Barcelona English Language and Literature Studies, 12. Retrieved from http://www.publicacions.ub.es/ revistes/bells12/PDF/art09.pdf.

19 Mele-Marrero, M. (2017). The evolution of self-mentioning in 18thc CETA and CHET Coruña Corpus. In Alonso Almeida, F. (Ed.), Stancetaking in Late Modern English Scientific Writing: Evidence from the Coruña Corpus: Essays in Honour of Santiago González y Fernández-Corugedo, (pp. 57-71).Valencia: Universitat Politécnica de Valencia.

20 Moskowich, I. (2017). Pronouns as stance markers in the Coruña Corpus: An analysis of the CETA, CEPhiT and CHET. In Alonso Almeida, F. (Ed.), Stancetaking in Late Modern English Scientific Writing. Evidence from the Coruña Corpus. Essays in Honour of Santiago González y Fernández-Corugedo, (pp. 73-91). Valencia: Universitat Politécnica de Valencia.

21 Moskowich, I., \& Crespo, B. (2014). Stance is present in scientific writing, indeed. Evidence from the Coruña Corpus of English Scientific Writing. Token: A Journal of English Linguistics, 3, 91-114.

22 Myers, G. (1989). The pragmatics of politeness in scientific articles. Applied Linguistics, 10(1), 1-35. https://doi.org/10.1093/applin/10.1.1

23 Myers, G. (1992). In this paper we report...: Speech acts and scientific facts. Journal of Pragmatics, 17, 295-313. https://doi.org/10.1016/03782166(92)90013-2

24 Pennycook, A. (1994). The politics of pronouns. English Language Teaching, 48(2), 173-178. https://doi.org/10.1093/elt/48.2.173

25 Quirk, R., Greenbaum, S., Leech, G. \& Svartvik, J. (1985). A Comprehensive Grammar of the English Language. New York: Longman.

26 Teich, E. (2019). Corpus-driven investigation of language use, variation and change resources, models, tools. CLARIN Annual Conference 2019, Leipzig. Retrieved from http://videolectures. net/clarinannualconference2019_teich_corpus_driven/

27 Zohar, I. (2015). Linguistic-rhetorical investigation of concession structures in a confrontational academic context. REDIS: Revista de Estudos do Discurso, 4, 66-94. 


\section{Isabel Moskowich. Asmeniniai ivardžiai CHET ir CECheT tekstynuose: autoriaus mato- mumas ir kiti niuansai}

Šio straipsnio tikslas yra ištirti pirmojo asmens jivardžių vartojimą vèlyvosios šiuolaikinès anglu kalbos mokslinio stiliaus darbuose. Remiantis ankstesniais tyrimais (Moskowich, 2017), atlikta kokybinè analizè. Ivardžiai sugrupuoti pagal penkias funkcijas, kurios turi skirtingą pragmatinę reikšmę. Tyrimo metu sudarytas ivardžiuotinių formų dažniu sąrašas, pateiktos užklausos naudojantis paieškos įrankiu, o gauti pavyzdžiai suskirstyti pagal funkcijas. Tyrime siekiama atsakyti i šiuos klausimus: ar laikui bègant pereinama nuo prozos, orientuotos i autoriu, prie prozos, orientuotos i objektą; ar moterys rašytojos savo rašto darbuose labiau matomos nei vyrai; ar humanitarinių mokslu tekstai yra subjektyvesni nei tiksliuju mokslų tekstai. Išnagrinejjus tiriamają medžiagą, straipsnyje paaiškinama asmeninių ivardžių reikšmè mokslineje anglu kalboje. Tyrimo rezultatai padeda atskleisti autorių matomumo išraiškas rašto darbuose ir autoriu požiūri i skaitytoją bei darbo tematiką.

\section{Isabel Moskowich}

Tenured full professor, MuStE (www.udc.es/grupos/muste), University of A Coruña, Spain

Research interests

Corpus linguistics, discourse analysis, scientific writing, history of the English language, late Modern English

\section{Address}

Department of Languages and Literatures (English Studies), Faculty of Philology, Rúa Lisboa 7, Campus da Zapateira 15008 A Coruña, Spain

\section{E-mail}

imoskowich@udc.es 